\title{
Effect of automatic cluster remover settings on production, udder health, and milking duration
}

\author{
J. G. Jago, ${ }^{1}$ J. L. Burke, and J. H. Williamson \\ DairyNZ, Private Bag 3221, Hamilton 3240, New Zealand
}

\begin{abstract}
This study evaluated the effect of 4 criteria for determining the end-point of milking on milk yield, milk composition, completeness of milking-out, teat skin condition, somatic cell count (SCC), and the incidence of clinical mastitis (CM) in pasture-based dairy cows milked over $35 \mathrm{wk}$. The objective was to reduce milking duration without affecting milk production, SCC, or CM. Milking end-point treatments were as follows: cluster removed at a milk flow rate of $0.2 \mathrm{~kg} / \mathrm{min}$ (ACR200); cluster removed at a milk flow rate of 0.4 $\mathrm{kg} / \mathrm{min}$ (ACR400); cluster removed at a milk flow rate of $0.2 \mathrm{~kg} / \mathrm{min}$ or at a maximum cluster attachment time from d 5 of lactation (MaxTEarly); and cluster removed at a milk flow rate of $0.2 \mathrm{~kg} / \mathrm{min}$ until an average of $63 \pm 21 \mathrm{~d}$ in milk, then cluster removed at a milk flow rate of $0.2 \mathrm{~kg} / \mathrm{min}$ or a maximum cluster attachment time (MaxTPeak). Maximum cluster attachment times were set at $7.5 \mathrm{~min}$ and $5.4 \mathrm{~min}$ for morning and afternoon milkings, respectively. Cows (approximately 94/treatment) were assigned to treatment at calving and milked twice daily at intervals of 9 and $15 \mathrm{~h}$. Milking duration was shorter for ACR400, MaxTEarly, and MaxTPeak compared with ACR200. During wk 1 to 15, milk, protein, and lactose yields were less for MaxTEarly than for ACR400 and MaxTPeak, but not different from ACR200. During wk 16 to 35 and over the entire experiment, total milk, fat, protein, and lactose yields did not differ among treatments. Teat condition did not differ among the 4 treatments. Postmilking strip yield in wk 12 was greatest for MaxTEarly and least for ACR200; at wk 27, however, treatment had no effect on the completeness of milking-out. No differences were observed in either teat condition or the proportion of cows with at least 1 case of CM during the 35 wk. Somatic cell count was low across all treatments, but highest for ACR400. Increasing the automatic cluster remover threshold setting from 0.2 to $0.4 \mathrm{~kg} / \mathrm{min}$ decreased milking duration without affect-
\end{abstract}

Received November 26, 2009.

Accepted March 1, 2010.

${ }^{1}$ Corresponding author: jenny.jago@dairynz.co.nz ing milk production, CM, or teat condition. Combining a cluster removal milk flow threshold setting with a maximum cluster attachment time, when applied from either early lactation or from peak lactation, reduced milking duration without affecting milk production, CM, or SCC. Both strategies have potential to improve milking efficiency in dairy herds in which premilking preparation is minimal.

Key words: milking duration, automatic cluster remover setting, milking efficiency, mastitis

\section{INTRODUCTON}

With increasing herd size, a reduction in the availability of skilled labor, and a need to minimize operating costs, on-farm milking practices that improve labor productivity (cows per labor unit) need to be examined. The labor required for milking in intensive pastoral dairy operations typically accounts for 33 to $55 \%$ of all labor input on farms (O'Brien et al., 2004; O'Donovan et al., 2008; Taylor et al., 2009). Farmers are adopting more automation because it has the potential to reduce the number of people required to milk the herd and increases the information available for management decisions (Dela Rue, 2008). For example, the use of automatic cluster removers (ACR) is increasing on New Zealand and Australian dairy farms (Cuthbert, 2008; Watson, 2009). In New Zealand, 54\% of rotary dairies and $9 \%$ of herringbone dairies have installed ACR (Cuthbert, 2008). The proportion of dairies fitted with ACR increased from 28 to $40 \%$ on Australian farms from 2004 to 2009 (Watson, 2009).

The operating principle for ACR is to detach the cluster once milk flow has decreased below a preset level or switch point ( $\mathrm{kg} / \mathrm{min})$. An additional adjustment, usually called the ACR delay time, determines how long (s) the cluster remains attached after the switch point is reached. The choice of ACR setting influences milking duration but has been reported in several studies (Rasmussen, 1993; Stewart et al., 2002; Billon et al., 2009) to have no effect on production and udder health. Increasing the ACR threshold level from 0.2 to $0.4 \mathrm{~kg} / \mathrm{min}$ was reported to reduce milking duration without affecting milk yield, milk composition, or 
the incidence and prevalence of clinical and subclinical mastitis (Rasmussen, 1993). Subsequent reports have cited field experience in commercial dairies indicating that increasing the ACR setting from 0.32 to $0.59 \mathrm{~kg} /$ min or to an even higher threshold of $0.82 \mathrm{~kg} / \mathrm{min}$ can decrease milking duration while maintaining the quality and volume of milk harvested (Reid and Stewart, 1997; Stewart et al., 1999, 2002). In each of these studies, cows were milked according to best practice premilking preparation routines, which include cleaning and forestripping of teats. Few experimental studies have examined ACR settings for use with cows milked following minimal premilking routines such as those typically practiced in pasture-based settings. Clarke et al. (2004) observed that changing the ACR setting incrementally from $0.2 \mathrm{~kg} / \mathrm{min}$ to $0.5 \mathrm{~kg} / \mathrm{min}$ resulted in little reduction in the group milking duration.

A modification to the traditional ACR milk flow rate switch point settings, which combine a minimum flow rate threshold with a maximum cluster attachment duration, has been described by Clarke et al. (2004). This approach is designed to limit the effect of the slowest 20 to $30 \%$ of cows in a herd on total milking time, thereby reducing row times. This method has been applied successfully to cows in late lactation, reducing the maximum milking duration of the slowest-milking cows by up to $34 \%$ without a loss of milk yield (Clarke et al., 2004) or increases in SCC or the incidence of clinical mastitis (CM; Clarke et al., 2006). The results of subsequent studies indicated no adverse effects of this practice on udder health. Specifically, any change in SCC was not related to change in strip yield induced by incomplete milking (Clarke et al., 2008). There may therefore be potential to apply a combined ACR and maximum cluster attachment duration setting from the start of lactation to achieve maximum efficiency benefits; however, this has not been tested.

Four criteria for determining the end-point of milking were evaluated for their effects on production, udder health, SCC, teat skin condition, and milking duration in cows milked with minimal premilking routines. The objective was to reduce milking duration without adversely affecting milk production, SCC, or CM.

\section{MATERIALS AND METHODS}

\section{Animals and Treatments}

This study was approved by the Ruakura Animal Ethics Committee (Hamilton, New Zealand) and was conducted at the Westpac Taranaki Regional Research Farm (Taranaki, New Zealand) from July 2008 to March 2009. A total of 378 cows of mixed breed (25\% Jersey, 47\% Friesian, and 28\% Jersey-Friesian cross) and mixed age (average $4 \mathrm{yr}$, range $2-13 \mathrm{yr}$ ) were included in the study. At wk 8, when the majority of cows had calved, average BCS (scored from 1 to 10; Roche et al., 2004) was $4.3 \pm 0.4$ and BW was $450 \pm 84.6 \mathrm{~kg}$. Cows were allocated to treatment at calving according to a predetermined random treatment order list. This ensured that treatments were balanced for calving date. Half the cows had calved by August 16, 2008. As cows calved they entered a postcalving colostrum herd. After an average of $5.8 \pm 3.8 \mathrm{~d}$ they entered the main milking herd. Once this herd reached 100 cows, a second herd was started. This continued until all cows had calved. Cows were managed in up to 6 herds during the experiment to accommodate paddock size at the research farm and to manage seasonal fluctuations in pasture growth efficiently; these herds were balanced for treatment and calving date. The herds were rotationally grazed on predominantly perennial ryegrass-white clover dominant pasture and supplemented with pasture silage when postgrazing residuals were less than target. They were managed according to the best practice management guidelines described by Macdonald and Penno (1998).

All cows were milked in the morning between 0530 and $0800 \mathrm{~h}$ and in the afternoon between 1450 and 1700 $\mathrm{h}$. The cows were milked in a 40 bail rotary dairy fitted with Metatron electronic milk meters, P21 bail controllers, ACR, and electronic identification tags (Metatron DairyPlan, GEA, Oelde, Germany). Teat cup liners (Westfalia 270, GEA) were new at the start of the experiment. The ACR delay setting (time delay between detecting low flow threshold and cluster removal) was set at $7 \mathrm{~s}$. Plant vacuum was set at $40 \mathrm{kPa}$. No routine washing, drying, or fore stripping of the teats occurred before the teat cups were applied. A commercially available teat sanitizer [1.5 parts Klenzade Teat Guard $50(0.5 \%$ iodine; Ecolab, St. Paul, MN) to 1.5 parts glycerine to 17 parts water] was applied to each cow manually by pressurized spray after each milking.

All cows were milked with an ACR setting of $0.2 \mathrm{~kg} /$ min from calving until they entered a milking herd. The treatments differed in the determination of the milking end-point and were as follows: cluster removed at a milk flow rate of $0.2 \mathrm{~kg} / \mathrm{min}$ (ACR200); cluster removed at a milk flow rate of $0.4 \mathrm{~kg} / \mathrm{min}$ (ACR400); cluster removed at a milk flow rate of $0.2 \mathrm{~kg} / \mathrm{min}$ or at a set maximum cluster attachment time (MaxTEarly); and cluster removed at a milk flow rate of $0.2 \mathrm{~kg} / \mathrm{min}$ until an average of $63 \pm 21 \mathrm{~d}$ of lactation, then cluster removed at a milk flow rate of $0.2 \mathrm{~kg} / \mathrm{min}$ or a set maximum time or flow rate (MaxTPeak). The different ACR threshold treatment settings were applied to individual cows using the Metatron (GEA) herd management software. 
The maximum cluster attachment duration was set using the equation described in the CowTime (2006) guidelines: duration $(\mathrm{min})=1.22 \times$ yield $^{0.71}$, where yield is the average herd milk yield for a milking session. Typically, the maximum cluster attachment time is calculated using the average herd yield and milking interval. However, because the treatment was applied early in lactation and before peak herd yield was known, historical data were used to estimate a peak yield of 23 $\mathrm{L}$ and a milking interval of 9 and $15 \mathrm{~h}$. A separate calculation of the prescribed maximum milking duration was made for morning and afternoon milkings. Maximum cluster attachment time was set at $7.5 \mathrm{~min}$ and $5.4 \mathrm{~min}$ for the morning and afternoon milkings, respectively. The target was for approximately 20 to $30 \%$ of milkings to reach the maximum cluster attachment duration. The treatment was applied by changing the maximum time setting (Metatron herd management software) for ACR detachment before every morning and afternoon milking for the MaxTEarly group and from wk 16 for the MaxTPeak group. The expectation was that the maximum cluster attachment time would change every 2 to $4 \mathrm{wk}$ as daily milk yield reduced once peak milk yield had been achieved, as described in the CowTime (2006) guidelines. However, the proportion of cows reaching the maximum cluster attachment time exceeded the 20 to $30 \%$ target; it was, therefore, decided to maintain the same maximum cluster attachment time settings throughout the 35-wk experiment. The same maximum cluster attachment time was set for the cows in the MaxTPeak treatment from wk 16 of the experiment, just after peak milk yields had been achieved.

\section{Milking Duration, Milk Yield, and Milk Composition Measurements}

After calving, individual milk yield, milking duration, and average milk flow rate were recorded automatically at every milking (GEA). Composite milk samples (morning and afternoon milking) were collected from each cow weekly from wk 1 to 13 and then every 2 wk thereafter. Milk fat and protein concentrations were determined using an infrared milk analyzer (Milko Scan 133B Analyzer, Foss Electric, Hillerød, Denmark) and SCC was determined using an automated cell counter (Fossomatic 5000, Foss Electric).

\section{Completeness of Milking, Teat Condition, and Mastitis}

Postmilking strip yield was determined at the morning milking in wk 12 and 27 . The cows remained on the platform, the cluster was reattached within 2 min of the normal end of milking, and downward pressure was applied until no further milk could be removed from the udder.

Teat condition was scored for all teats of all animals twice (wk 12 and 27). Teat scoring was carried out by an experienced assessor who scored all the cows at the afternoon milking using methodology similar to that described in Shearn and Hillerton (1996). Individual teats were assessed for the presence of warts and swelling at the teat base and assigned a score from 0 to 4 corresponding to an increasing degree of teat end hyperkeratosis or roughness.

Cows with CM were identified by staff and treated according to recommended best on-farm practice. Clinical mastitis was defined as a quarter displaying any of the following signs: flakes or clots in the milk, watery or discolored milk, and hot or swollen mammary tissue. Before treatment, foremilk samples were collected aseptically from the infected quarters for bacteriological analysis. Teat ends were first scrubbed with cotton wool swabs soaked in $70 \%$ alcohol and allowed to dry. The first 2 to 3 squirts of milk were discarded and approximately $20 \mathrm{~mL}$ was collected in a sterile container. Identification of bacteria in milk was performed using recommended procedures (NMC, 1999). A subsample of $10 \mu \mathrm{L}$ of milk from each quarter was streaked onto 1 quadrant of agar plate containing $5 \%$ sheep blood and $0.1 \%$ esculin (Fort Richard Laboratories, Otahuhu, Auckland, New Zealand) and incubated for $48 \mathrm{~h}$ at $37^{\circ} \mathrm{C}$. Presumptive identification of isolates was made on the basis of Gram stain, colony morphology, catalase test, patterns of hemolysis, esculin reaction, inulin fermentation, sodium hippurate reaction, growth in BHI broth with $6.5 \%$ salt, and Christie, Atkins, Munch-Petersen (CAMP) test. For gram-negative isolates, presumptive identification included lactose reaction, citrate utilization, motility development, oxidase reaction, and triple sugar iron slant reaction.

\section{Statistical Analyses}

Of the 378 animals involved in this experiment, 7 first-lactation and 35 multiparous cows were excluded from the analysis because they died, were culled, or had large periods of missing data caused by problems interpreting the electronic data or failure of the electronic identification system, leaving a total of 336 animals in the analysis. Those animals removed from the analysis included $8,10,11$, and 11 cows from the ACR200, ACR400, MaxTEarly, and MaxTPeak treatment groups, respectively.

Daily milk yields were summed to produce a total weekly milk yield for each animal. Daily fat and protein yields were calculated from the composite morning and 
Table 1. Milk production, proportion of cows with at least 1 case of clinical mastitis (CM), and SCC $\left(\log _{10}\right)$ in cows milked with 4 different end of milking criteria during wk 1 to 15 (before cluster attachment was restricted to a maximum time for MaxTPeak cows), wk 16 to 35, and over the entire experimental period (wk 1-35)

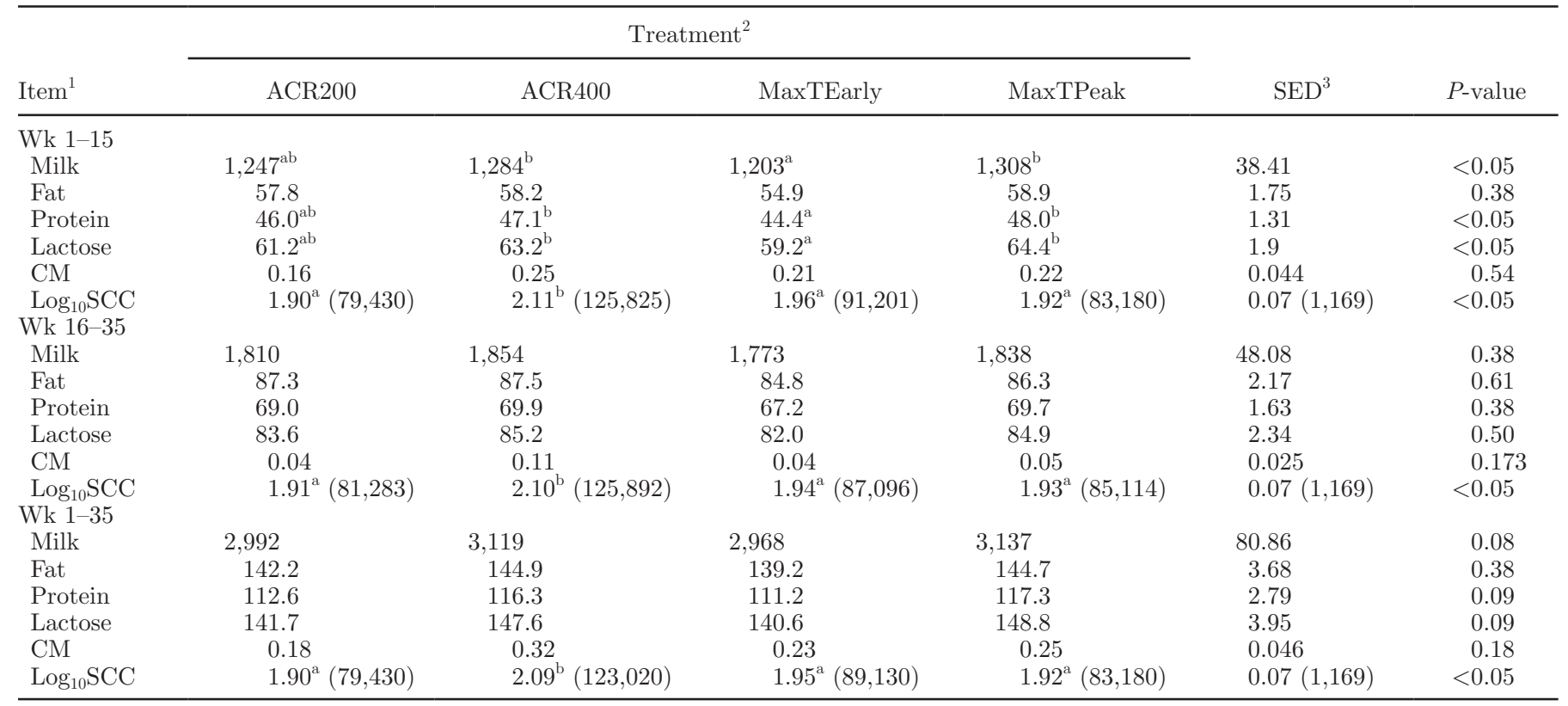

${ }^{\mathrm{a}, \mathrm{b}}$ Means in the same row with different superscripts are different $(P<0.05)$.

${ }^{1}$ Milk, fat, protein, and lactose $=\mathrm{kg} /$ cow. $\mathrm{CM}=$ proportion of cows with at least 1 case of $\mathrm{CM} . \quad \log _{10} \mathrm{SCC}=\log _{10} \mathrm{SCC}$; raw means $($ backtransformed SCC, cells $/ \mathrm{mL}$ ) in parentheses.

${ }^{2}$ Treatments: ACR200 = automatic cluster remover $(\mathrm{ACR})$ setting of $0.2 \mathrm{~kg} / \mathrm{min}$; ACR $400=\mathrm{ACR}$ setting of $0.4 \mathrm{~kg} / \mathrm{min}$; MaxTEarly $=$ ACR setting of $0.2 \mathrm{~kg} / \mathrm{min}$ or maximum machine on time of $7.5 \mathrm{~min}$ (a.m. milking) or 5.4 min (p.m. milking), whichever comes first; MaxTPeak = ACR setting of $0.2 \mathrm{~kg} / \mathrm{min}$ for wk 1-15, then ACR setting of $0.2 \mathrm{~kg} / \mathrm{min}$ or maximum machine on time of $7.5 \mathrm{~min}$ (a.m. milking) or $5.4 \mathrm{~min}$ (p.m. milking), whichever comes first.

${ }^{3}$ Standard error of the difference. Values for CM are average SEM.

afternoon test samples of each cow and then summed to produce weekly totals. A teat end hyperkeratosis score for each cow was calculated by summing the score for each teat. The SCC data were not normally distributed, so a $\log _{10}$ transformation was applied before analysis. Data were analyzed by calculating summaries of the data for 3 periods (wk 1-15, wk 16-35, and wk 1-35) for each cow and then analyzing these summary measures using linear models, including breed (Jersey, Friesian, Jersey-Friesian cross), parity (primiparous, multiparous), calving date, and treatment in the model. If the overall $F$-test was significant $(P<0.05)$, the significance of differences between individual treatments was determined using a $t$-test. The proportion of cows with

Table 2. Average milking duration (percentage of milkings in parentheses) equal to or greater than 7.5 min for the a.m. milking or 5.4 min for the p.m. milking for cows milked with 4 different end of milking criteria

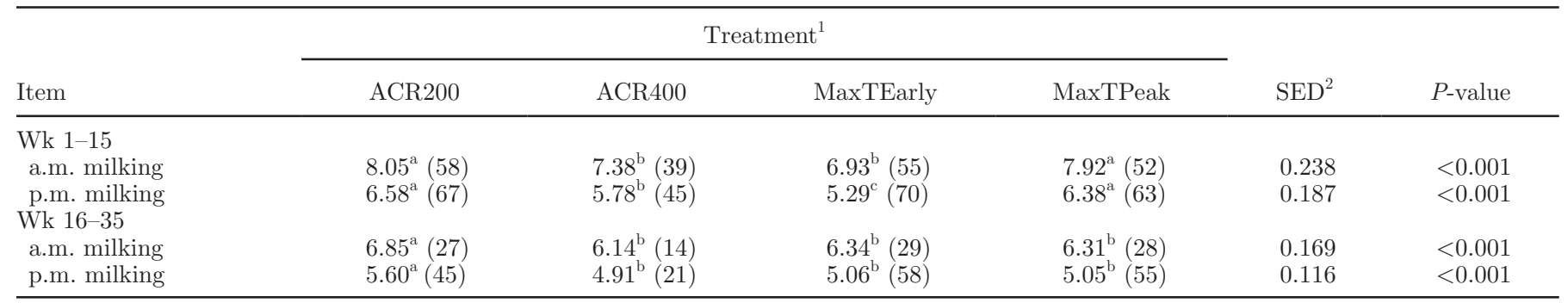

${ }^{\mathrm{a}-\mathrm{c}}$ Means in the same row with different superscripts are different $(P<0.05)$.

${ }^{1}$ Treatments: ACR200 = automatic cluster remover $(\mathrm{ACR})$ setting of $0.2 \mathrm{~kg} / \mathrm{min} ; \mathrm{ACR} 400=\mathrm{ACR}$ setting of $0.4 \mathrm{~kg} / \mathrm{min} ; \mathrm{MaxTEarly}=\mathrm{ACR}$ setting of $0.2 \mathrm{~kg} / \mathrm{min}$ or maximum machine on time of $7.5 \mathrm{~min}$ (a.m. milking) or $5.4 \mathrm{~min}$ (p.m. milking), whichever comes first; MaxTPeak = ACR setting of $0.2 \mathrm{~kg} / \mathrm{min}$ for wk 1-15, then ACR setting of $0.2 \mathrm{~kg} / \mathrm{min}$ or maximum machine on time of $7.5 \mathrm{~min}$ (a.m. milking) or 5.4 min (p.m. milking), whichever comes first.

${ }^{2}$ Standard error of the difference. 
at least 1 instance of $\mathrm{CM}$ was calculated. Proportions were analyzed using generalized linear models with logit link and binomial error distribution; the model included breed (Jersey, Friesian, Jersey-Friesian cross), age group (primiparous, multiparous), calving date, and treatment.

\section{RESULTS}

\section{Production and Milk Composition}

Mean DIM at the end of the experiment was $212 \pm$ $26,213 \pm 24,214 \pm 23$, and $214 \pm 21$ for ACR200, ACR400, MaxTEarly, and MaxT Peak, respectively. In wk 1 to 15 , MaxTEarly had a lower $(P<0.05)$ milk, protein, and lactose yield than ACR400 and MaxTPeak, but was not different from ACR200, which was not different from either ACR400 or MaxTPeak (Table 1). Fat yield did not differ among the 4 treatments. In wk 16 to 35 and over the entire experiment (wk 1-35), total milk, fat, protein, and lactose yields did not differ $(P>0.05)$ among treatments (Table 1$)$.

\section{Milking Duration}

Cows in MaxTEarly and ACR400 had the shortest $(P<0.05)$ milking duration at both the morning and afternoon milkings during wk 1 to 15 (Table 2). During wk 16 to 35, MaxTEarly, ACR400, and MaxTPeak had a shorter $(P<0.05)$ milking duration at both the morning and afternoon milkings than ACR200, but were not different from each other. Average milk flow rate $(\mathrm{kg} / \mathrm{min})$ was greater for ACR400 and MaxTEarly cows than for ACR200 and MaxTPeak cows during wk 1 to $15($ ACR $200=1.55$, ACR $400=1.75$, MaxTEarly $=1.76$, MaxTPeak $=1.68 ; \mathrm{SED}=0.07 ; P<0.05)$, but did not differ between treatments during wk 16 to 35 $($ ACR200 $=1.38$, ACR $400=1.52$, MaxTEarly $=1.44$, MaxTPeak $=1.49 ;$ SED $=0.06 ; P=0.101)$.

Overall, the proportion of cows in each treatment that reached the MaxT time was greater at the afternoon than the morning milking (Table 2). The proportion of cows that would have theoretically reached the MaxT time had it been applied was greater for the ACR200 treatment than the ACR400 treatment (Table 2). A greater proportion of ACR200, MaxTEarly, and MaxTPeak cows reached the MaxT time than cows in ACR400. The maximum target of 20 to $30 \%$ of milkings reaching the MaxT time was achieved only by cows in ACR200 at the morning milking in wk 16 to 35 and the cows in ACR400 at the morning and afternoon milkings in wk 16 to 35 .

\section{Strip Yield Assessment and Teat Measurements}

Postmilking strip yield was greater $(P<0.05)$ for cows in MaxTEarly than cows in ACR200, ACR400, or MaxTPeak at wk 12 (Table 3). When measured at wk 27, however, the volume of strip yield did not differ among treatments $(P>0.05)$.

Teat end hyperkeratosis score was minimal and did not differ among treatments in wk $12($ ACR200 $=0.98$, ACR400 $=0.72$, MaxTEarly $=0.87$, MaxTPeak $=$ 1.07; $\mathrm{SED}=0.237 ; P=0.56)$ or wk $27(\mathrm{ACR} 200=$ 1.15, ACR $400=0.85$, MaxTEarly $=1.03$, MaxTPeak $=0.93 ;$ SED $=0.233, P=0.80)$. The proportion of cows with swelling at the teat base was high $(0.41$ in both wk 12 and 27), but did not differ $(P>0.05)$ among treatments. The proportion of teats with warts was low ( $<5 \%$ for all treatments) and did not differ among treatments.

Table 3. Milk yield and strip milk yield expressed as a percentage of total yield, measured at an a.m. milking at wk 12 and 27 for cows milked with 4 different end of milking criteria

\begin{tabular}{|c|c|c|c|c|c|c|}
\hline Item & \multicolumn{4}{|c|}{ Treatment $^{1}$} & $\mathrm{SED}^{2}$ & $P$-value \\
\hline \multicolumn{7}{|l|}{ Week 12} \\
\hline Strip yield (kg) & $0.20^{\mathrm{a}}$ & $0.61^{\mathrm{a}}$ & $1.24^{\mathrm{b}}$ & $0.22^{\mathrm{a}}$ & 0.292 & $<0.001$ \\
\hline Total milk yield (\%) & 1.8 & 5.5 & 10.4 & 1.7 & & \\
\hline \multicolumn{7}{|l|}{ Week 27} \\
\hline
\end{tabular}

${ }_{\mathrm{a}, \mathrm{b}}$ Means in the same row with different superscripts are different $(P<0.05)$.

${ }^{1}$ Treatments: ACR200 = automatic cluster remover $($ ACR $)$ setting of $0.2 \mathrm{~kg} / \mathrm{min} ;$ ACR $400=$ ACR setting of $0.4 \mathrm{~kg} / \mathrm{min} ; \mathrm{MaxTEarly}=\mathrm{ACR}$ setting of $0.2 \mathrm{~kg} / \mathrm{min}$ or maximum machine on time of $7.5 \mathrm{~min}$ (a.m. milking) or $5.4 \mathrm{~min}$ (p.m. milking), whichever comes first; MaxTPeak = ACR setting of $0.2 \mathrm{~kg} / \mathrm{min}$ for wk 1-15, then ACR setting of $0.2 \mathrm{~kg} / \mathrm{min}$ or maximum machine on time of $7.5 \mathrm{~min}$ (a.m. milking) or 5.4 min (p.m. milking), whichever comes first.

${ }^{2}$ Standard error of the difference. 
Table 4. Incidence of clinical mastitis by pathogen for cows milked with 4 different end of milking criteria ${ }^{1}$

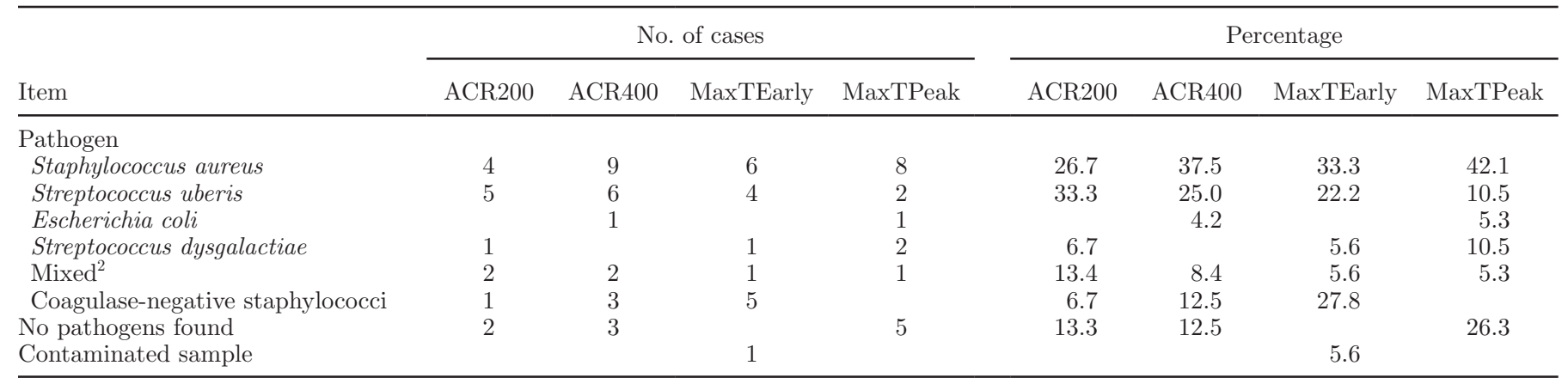

${ }^{1}$ Treatments: ACR200 = automatic cluster remover $(\mathrm{ACR})$ setting of $0.2 \mathrm{~kg} / \mathrm{min}$; ACR $400=\mathrm{ACR}$ setting of $0.4 \mathrm{~kg} / \mathrm{min}$; MaxTEarly $=\mathrm{ACR}$ setting of $0.2 \mathrm{~kg} / \mathrm{min}$ or maximum machine on time of $7.5 \mathrm{~min}$ (a.m. milking) or $5.4 \mathrm{~min}$ (p.m. milking), whichever comes first; MaxTPeak = ACR setting of $0.2 \mathrm{~kg} / \mathrm{min}$ for wk 1-15, then ACR setting of $0.2 \mathrm{~kg} / \mathrm{min}$ or maximum machine on time of $7.5 \mathrm{~min}$ (a.m. milking) or $5.4 \mathrm{~min}$ (p.m. milking), whichever comes first.

${ }^{2}$ Staphylococcus aureus/Streptococcus uberis; Staphylococcus aureus/Streptococcus dysgalactiae; Streptococcus uberis/coagulase-negative staphylococci.

\section{Udder Health}

Somatic cell count was greater $(P<0.05)$ for cows in ACR400 than cows in ACR200, MaxTEarly, and MaxTPeak treatments in wk 1 to 15 , wk 16 to 35 , and over the entire experiment (Table 1). Weekly SCC data indicated that the SCC of the MaxTPeak group was greater than for the other treatment groups from the start of the experiment. All 4 treatment groups followed a similar temporal trend in SCC over the $35 \mathrm{wk}$.

There were a total of 128 quarter cases of CM involving 83 cows. Removing multiple (repeat) infections, 112 quarter cases occurred in 83 cows. Of these 62.5 and $37.5 \%$ were in the rear and front quarters, respectively. The proportion of quarters with $\mathrm{CM}$ was $0.07,0.10$, 0.08, and 0.08 for ACR200, ACR400, MaxTEarly, and MaxTPeak, respectively. The proportion of cows with at least 1 instance of $\mathrm{CM}$ did not differ among treatments (Table 1).

Seventy-six $(68 \%)$ of the 112 quarter cases were assessed for bacteriology (Table 4). Major pathogens including Staphylococcus aureus, Streptococcus uberis, Streptococcus dysgalactiae, and Escherichia coli were isolated in 56 of the $76(73.7 \%)$ infected quarters, with Staphylococcus aureus the predominant pathogen (38.2\% of quarters). Coagulase negative staphylococci were evident in $11(14.5 \%)$ samples; $10(13.2 \%)$ samples did not grow bacteria and $1(1.3 \%)$ sample was contaminated.

\section{DISCUSSION}

The results of this experiment have shown that milking duration can be substantially reduced by setting a maximum cluster attachment time in conjunction with an ACR threshold setting of $0.2 \mathrm{~kg} / \mathrm{min}$ from the start of lactation in pasture-based dairy cows milked with minimal premilking routines. These time efficiencies are achieved without adversely affecting SCC or the incidence of CM.

\section{Milking Performance}

Decreasing cluster attachment time leads to improved labor efficiency (cows milked/h). In this study, increasing the ACR threshold setting by $0.2 \mathrm{~kg} / \mathrm{min}$ decreased milking duration by between 0.75 and $0.92 \mathrm{~min} / \mathrm{cow}$ per milking. This substantial reduction was greatest in early lactation and persisted throughout lactation and was greater than that reported in other studies (Rasmussen, 1993; Stewart et al., 2002; Magliaro and Kensinger, 2005).

Maintaining a low ACR threshold and setting a maximum cluster attachment time produced a greater reduction in average milking duration in the early stage of lactation than just increasing the ACR setting by 0.2 $\mathrm{kg} / \mathrm{min}$. The large reduction of 1.12 to $1.29 \mathrm{~min} / \mathrm{cow}$ per milking, relative to the ACR200 cows, reduced to just over $0.5 \mathrm{~min} /$ milking after peak lactation. This is attributable to the same fixed maximum cluster attachment time being applied throughout the experiment and reflects the reduction in milking duration of the ACR200 cows as a result of reducing milk yields as lactation progresses. Smaller yet significant reductions in average milking duration were reported by Clarke et al. (2004) when a maximum cluster attachment time was set relative to a control group with an ACR set at $0.2 \mathrm{~kg} / \mathrm{min}$ in cows producing similar milk yields $(14.3-21.3 \mathrm{~L} / \mathrm{d})$.

The MaxTEarly and MaxTPeak treatments incorporating a flow rate threshold and maximum cluster attachment time resulted in even larger time savings 
considering row times because the slowest cow determines the time it takes to milk a row or batch of cows, particularly in a herringbone or parallel parlor, if unit on time is not the limiting factor. In a rotary parlor, reducing the maximum milking time allows the platform speed to be increased, improving cow throughput. No cow was milked for longer than $7.5 \mathrm{~min}$ in the morning or $5.4 \mathrm{~min}$ in the afternoon in the MaxTEarly treatment, which sets an upper limit for any batch of cows. In contrast, whereas the ACR400 treatment had a similar average milking duration, between 14 and $45 \%$ of cow milkings were equal to or exceeded the maximum duration of the MaxT Early treatment. In comparison with a maximum cluster attachment time, an ACR400 setting would therefore slow overall milking time.

The preparation of the udder and teats, undertaken before attaching the clusters, affects the pattern of milk flow from the udder. Without adequate tactile teat stimulation and oxytocin release in the premilking phase, milk ejection will occur after the teat cups are attached, resulting in slow initial milk flow from the udder cistern. This is followed by a period of little or no milk flow before milk ejection occurs and a longer period of low flow at the end of milking (Bruckmaier and Blum, 1998; Bruckmaier and Hilger, 2001). In most other similar studies (e.g., Rasmussen, 1993; Stewart et al., 2002) cows underwent premilking preparation (washing, or tactile stimulation, or both) before teat cup attachment; in contrast, in the current study cows received no premilking preparation. This may in part explain the larger reduction in milking duration in this study compared with those reported by Rasmussen (1993) and Stewart et al. (2002).

A greater proportion of individual milkings in all treatment groups reached the maximum cluster attachment time than was expected. Guidelines published in CowTime (2006) suggest a target of 20 to $30 \%$ of cows having their milking shortened when applying a maximum cluster attachment time strategy. These guidelines have been produced when comparing milking durations to an ACR threshold setting of $0.4 \mathrm{~kg} / \mathrm{min}$. In the current study, the ACR400 cows reached this target from wk 16 through 35 but would have exceeded the 20 to $30 \%$ target during the first 15 wk of lactation. The data may suggest that the cows in this study were generally slow milking. The reason for this is uncertain; it may be partially explained, however, by the lack of tactile stimulation before teat cup attachment extending the length of milking (Bruckmaier and Hilger, 2001; Clarke et al., 2004).

Postmilking strip yields are used to assess completeness of milking. It is generally recommended that average strip yields should not exceed more than $0.5 \mathrm{~L} / \mathrm{cow}$ for more than $20 \%$ of the herd (Brightling et al., 2000). Only cows in the MaxTEarly and ACR400 treatments did not meet these recommended guidelines and only when measured in the first 15 wk of lactation. Very high strip yields of $1.24 \mathrm{~kg}$ of milk/cow were recorded in the MaxTEarly treatment in wk 12, suggesting that significant milk was left behind in the udder cistern at peak milk production because of the cluster being removed when maximum cluster attachment time was reached.

\section{Production}

It is well known that reducing milking frequency (e.g., once a day milking) lowers milk production but that there are substantial differences among breeds and between individuals (Clark et al., 2006). The effects of incomplete milking on production are less clear. Very early experiments cited by Dodd and Griffin (1979) dating back to 1936 indicated that lactation yields were reduced by about $3 \%$ when $0.5 \mathrm{~kg}$ of milk was left in an udder after milking. In one of the few published studies on fixed-time milking, O'Shea (1974) reported that milking cows at a fixed time of either $6.5 \mathrm{~min}$ or 4.5 min at both morning and afternoon milkings over an entire lactation did not affect milk yield, milk composition, or milking characteristics when compared with a control group from which the clusters were removed when milk flow rate dropped to $0.18 \mathrm{~kg} / \mathrm{min}$. Production differences similar to the results presented here have been found when ACR threshold settings were increased over a 36-wk experiment (Rasmussen, 1993) and over shorter periods (Stewart et al., 2002; Clarke et al., 2004; Magliaro and Kensinger, 2005; Billon et al., 2009).

Despite the large differences in milking duration and increased postmilking strip yields evident in the ACR400 and MaxTEarly treatments, in the current study there was no effect of ACR setting on milk yield, milk fat, protein, or lactose when measured over the entire 35-wk experiment. Milk production, with the exception of fat yield, however, was lower in the MaxTEarly treatment cows during the first $15 \mathrm{wk}$ of the experiment. It is noteworthy, however, that this difference appears to be mainly attributable to higher milk production by the MaxTPeak group of cows that, during this period, were not different from the ACR200 group in milking end-point criteria (i.e., both groups had the ACR set to $0.2 \mathrm{~kg} / \mathrm{min}$ ) and did not differ in any of the production measures. Nevertheless, there is an indication that severe truncation of milking, resulting in increased postmilking strip yields, may suppress milk production in early lactation; over a lactation, however, these dif- 
ferences are inconsequential. It appears that milking time can be substantially shortened without significant detrimental effects on milk production characteristics.

\section{Udder Health}

In this study, the incidence of CM was not affected by raising the ACR threshold setting or applying a maximum milking time; however, SCC was increased at the higher ACR threshold setting. There is a common belief that incomplete milking of cows leads to mastitis (Thiel and Dodd, 1979) despite the literature being inconsistent. Some studies have reported a higher SCC in undermilked infected but not uninfected quarters (Schalm and Mead, 1943; Napper and Williamson, 1983), whereas other studies (e.g., reviewed by O'Shea, 1987) reported that small quantities of milk left in the udder do not increase new infection rate or CM. More recent studies such as those by Rasmussen (1993) reported a lower incidence of $\mathrm{CM}$ when the ACR threshold was raised from 0.2 to $0.4 \mathrm{~kg} / \mathrm{min}$. A series of studies by Australian researchers on research and commercial farms (Clarke et al., 2004, 2006, 2008) indicated that leaving some milk behind in udders did not adversely affect CM or SCC. The lack of effect of either increasing the ACR milk flow rate threshold or setting a maximum cluster attachment duration on rates of $\mathrm{CM}$ provides further evidence that leaving a small amount of milk behind in the udder does not necessarily lead to increased $\mathrm{CM}$ within the range of milk yield investigated.

The SCC was greater in the ACR400 group when compared with the other treatments. However, given that the increased SCC was evident from the start of the experiment, that the temporal trends for the 4 treatment groups were similar, that applying a maximum milking time resulted in increased postmilking strip yields without a corresponding increase in SCC, and that in other studies (Rasmussen, 1993; Clarke et al., 2004; Billon et al., 2009) increasing the ACR threshold setting did not result in an increase in SCC, the evidence is not strong in support of a higher ACR threshold setting adversely affecting udder health.

\section{CONCLUSIONS}

Increasing the ACR threshold setting from 0.2 to 0.4 $\mathrm{kg} / \mathrm{min}$ decreased milking duration without affecting milk production, CM, or teat condition; however, it did increase SCC inconsequentially. Combining an ACR milk flow threshold setting with a maximum cluster attachment time, when applied from either early lactation or from peak lactation, reduced milking duration without affecting milk production, CM, or SCC. Both strategies have potential for improving milking efficiency in pasture-based dairy herds in which premilking preparation is minimal.

\section{ACKNOWLEDGMENTS}

This study was part of a program of research funded by DairyNZ (Hamilton, New Zealand; project number SY704). The authors acknowledge Westpac Taranaki Research Farm (Taranaki, New Zealand) staff for animal management and milking, Barbara Dow (DairyNZ) for assistance with the data analysis, and John Roche (DairyNZ) for comments on the manuscript.

\section{REFERENCES}

Billon, P., V. Gaudin, and T. Huneau. 2009. Recherche du debit optimal de lait au moment de la depose des faisceaux trayeurs chez la vache laitiere. Compte rendu no 140731006. Institut de l'Elevage, Paris, France.

Brightling, P., G. Mein, A. Hope, J. Malmo, and D. Ryan. 2000. CountDown Downunder Technical Notes for Mastitis Control. Dairy Research and Development Corporation, Melbourne, Australia.

Bruckmaier, R. M., and J. W. Blum. 1998. Oxytocin release and milk removal in ruminants. J. Dairy Res. 81:939-949.

Bruckmaier, R. M., and M. Hilger. 2001. Milk ejection in dairy cows at different degrees of udder filling. J. Dairy Res. 68:369-376.

Clark, D. A., C. V. C. Phyn, M. J. Tong, S. J. Collis, and D. Dalley. 2006. A systems comparison of once- versus twice-daily milking of pastured dairy cows. J. Dairy Sci. 89:1854-1862.

Clarke, T., D. Cole, and R. K. Greenall. 2006. Shorter milking times research program. Technical Report. National Milk Harvesting Centre, Ellinbank, Victoria, Australia.

Clarke, T., E. M. Cuthbertson, R. K. Greenall, M. C. Hannah, and D. Shoesmith. 2008. Incomplete milking has no detectable effect on somatic cell count but increased cell count appears to increase strip yield. Aust. J. Exp. Agric. 48:1161-1167.

Clarke, T., E. M. Cutherbertson, R. K. Greenall, M. C. Hannah, and D. Shoesmith. 2004. Milking regimens to shorten milking duration. J. Dairy Res. 71:419-426.

CowTime. 2006. CowTime Quick Note 1.5: Maximum milk out times (MMOT). http://www.cowtime.com.au/technical/QuickNotes/ Quicknote\%201.5.pdf Accessed Jun. 2008.

Cuthbert, S. 2008. DairyNZ milking practices and technology use survey. Page 40 in report prepared for DairyNZ. LIC, Hamilton, New Zealand.

Dela Rue, B. 2008. Keeping on top with information. Pages 161-165 in Proc. 6th Dairy3 Conference, Apr. 14-16, Rotorua, New Zealand. Massey University, Palmerston North, New Zealand.

Dodd, F. H., and T. K. Griffin. 1979. Milking routines. Pages 179-200 in Machine Milking Technical Bulletin 1. C. C. Thiel and F. H. Dodd, ed. National Institute for Research in Dairying, Reading, UK.

Macdonald, K. A., and J. W. Penno. 1998. Management decision rules to optimise milksolid production on dairy farms. Proc. N.Z. Soc. Anim. Prod. 58:132-135.

Magliaro, A. L., and R. S. Kensinger. 2005. Automatic cluster remover setting affects milk yield and machine-on time in dairy cows. J. Dairy Sci. 88:148-153.

Napper, A. R., and J. H. Williamson. 1983. The effect of milking end point on somatic cell count. Page 55 in MAF Annual Report, 1982-1983. MAF, Wellington, New Zealand.

NMC. 1999. Laboratory Handbook on Bovine Mastitis. National Mastitis Council Inc, Madison, WI.

O'Brien, B., D. Gleeson, and K. O’Donovan. 2004. Labour expenditure on the milking process. Int. Dairy Topics J. 3:9-10. 
O’Donovan, K., B. O'Brien, D. J. Ruane, J. Kinsella, and D. Gleeson. 2008. Labour input on Irish spring-calving dairy farms and the effects of scale and seasonality. J. Farm Manage. 13:327-342.

O'Shea, J. 1974. Effect of duration of milking on bovine milk yield and composition, milking characteristics and mastitis. Isr. J. Agric. Res. 13:69-76.

O'Shea, J. 1987. Machine milking factors affecting mastitis. A literature review. Int. Dairy Fed. Bull. 217:5-32.

Rasmussen, M. D. 1993. Influence of switch level of automatic cluster removers on milking performance and udder health. J. Dairy Res. 60:287-297.

Reid, D. A., and S. C. Stewart. 1997. The effects on parlor performance by variations of detacher settings. Pages 101-104 in Proc. 36th Ann. Mtg. Natl. Mastitis Council. NMC, Madison, WI.

Roche, J. R., P. G. Dillon, C. R. Stockdale, L. H. Baumgard, and M. J. VanBaale. 2004. Relationship among international body condition scoring systems. J. Dairy Sci. 87:3076-3079.

Schalm, O. W., and S. W. Mead. 1943. The effect of incomplete milking on chronic mastitis caused by Streptococcus agalactiae. J. Dairy Sci. 26:823-832.
Shearn, M. F. H., and J. E. Hillerton. 1996. Hyperkeratosis of the teat duct orifice in the dairy cow. J. Dairy Res. 63:525-532.

Stewart, S., S. Godden, P. Rapnicki, D. Reid, A. Johnson, and S. Eicker. 2002. Effects of automatic cluster remover settings on average milking duration, milk flow and milk yield. J. Dairy Sci. 85:808-823.

Stewart, S. C., S. W. Eicker, D. A. Reid, and G. A. Mein. 1999. Using computerized data to find time for milk quality. Pages 116-122 in Proc. 38th Ann. Mtg. Natl. Mastitis Council. NMC, Madison, WI

Taylor, G., L. van der Sande, and R. Douglas. 2009. Technical Report for Smarter not Harder: Improving Labour Productivity in the Primary Sector, A Joint Dairy InSight and Sustainable Farming Fund Project, 30 April 2009. DairyNZ, Hamilton, New Zealand.

Thiel, C. C., and F. H. Dodd. 1979. Machine milking. Pages 236-285 in Technical Bulletin No. 1. National Institute for Research in Dairying, Reading, UK.

Watson, P. 2009. CowTime tracking survey 2009. http://www. cowtime.com.au/edit/Reports/COWTIME_TRACKING_ SURVEY_2009_REPORT_FINAL.PDF Accessed Aug. 2009. 